\title{
Identifying regional trade potential between selected countries in the African tripartite free trade area
}

\begin{tabular}{|c|c|}
\hline \multicolumn{2}{|c|}{$\begin{array}{l}\text { Authors: } \\
\text { Lorainne Ferreira }{ }^{1} \\
\text { Ermie A. Steenkamp }\end{array}$} \\
\hline \multicolumn{2}{|c|}{$\begin{array}{l}\text { Affiliations: } \\
{ }^{1} \text { School of Economic } \\
\text { Sciences, Faculty of Economic } \\
\text { and Management Sciences, } \\
\text { North-West University, } \\
\text { Potchefstroom, South Africa }\end{array}$} \\
\hline \multicolumn{2}{|c|}{$\begin{array}{l}\text { Corresponding author: } \\
\text { Lorainne Ferreira, } \\
\text { lorainne.ferreira@nwu.ac.za }\end{array}$} \\
\hline \multicolumn{2}{|c|}{$\begin{array}{l}\text { Dates: } \\
\text { Received: } 12 \text { Dec. } 2018 \\
\text { Accepted: } 21 \text { Nov. } 2019 \\
\text { Published: } 19 \text { Feb. } 2020\end{array}$} \\
\hline \multicolumn{2}{|c|}{$\begin{array}{l}\text { How to cite this article: } \\
\text { Ferreira, L. \& Steenkamp, } \\
\text { E.A., 2020, 'Identifying } \\
\text { regional trade potential } \\
\text { between selected countries } \\
\text { in the African tripartite free } \\
\text { trade area', South African } \\
\text { Journal of Economic and } \\
\text { Management Sciences 23(1), } \\
\text { a2936. https://doi.org/ } \\
\text { 10.4102/sajems.v23i1.2936 }\end{array}$} \\
\hline \multicolumn{2}{|c|}{$\begin{array}{l}\text { Copyright: } \\
\text { (C) 2020. The Authors. } \\
\text { Licensee: AOSIS. This } \\
\text { is licensed under the } \\
\text { Creative Commons } \\
\text { Attribution License. }\end{array}$} \\
\hline \multicolumn{2}{|l|}{ Read online: } \\
\hline 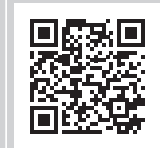 & $\begin{array}{l}\text { Scan this QR } \\
\text { code with your } \\
\text { smart phone or } \\
\text { mobile device } \\
\text { to read online. }\end{array}$ \\
\hline
\end{tabular}

Background: One of the most compelling arguments for regional trade and integration in Africa is that the African market is the most fragmented in the world, with only $16 \%$ of trade being within the continent. Furthermore, with 14 regional economic communities (RECs), the scale of integrated trading compared to the magnitude of trade is cause for concern. Africa could soon witness an important milestone on its path towards increased regional trade and improved integration with the implementation of the Tripartite Free Trade Agreement (TFTA) involving 26 countries. However, addressing overlapping memberships of the RECs and streamlining regulations, customs and border procedures can be a lengthy process.

Aim: In the meantime, this study aims to identify specific intra-regional trade opportunities among African countries to inform a more targeted approach to regional trade.

Methods: This article uses a unique approach based on the Decision Support Model (DSM) to identify intra-regional trade opportunities between the TFTA countries, taking into account each country's import demand and export supply.

Results: We determined 334 such opportunities among the 26 countries, of which 232 (almost $70 \%$ ) are newly recognised as not being exploited.

Conclusion: This economic potential calls for policymakers to take a more proactive approach in their actions and recommendations by targeting these trade opportunities.

Keywords: Tripartite Free Trade Agreement; intra-regional trade; free trade; Africa; decision support model.

\section{Introduction}

African countries are separated by more than 100 bilateral borders, which constrain trade and economic integration among these states. However, African governments have offered much support for regional trade and integration, embracing it as an important component of their development strategies (Hartzenberg 2011). As a result, Africa has $14^{1}$ regional economic communities (RECs), of which several have notable overlapping memberships. This has created a complex entanglement of political commitments and institutional requirements within the continent that has undermined regional integration. Moreover, it has complicated the coordination and harmonisation among African states in different RECs, causing counterproductive competition among them, with few success stories (Ndomo 2009). Only about $16 \%$ of Africa's total exports is intra-regional, compared to 68\% in Europe, 59\% in Asia and 55\% in America (UNCTAD 2019).

Africa could nevertheless soon witness an important milestone on its path towards increased trade integration with the implementation of the Tripartite Free Trade Agreement (TFTA). Covering 26 countries, representing almost half the population of the continent and a total gross domestic product (GDP) of approximately $\$ 1.3$ trillion, the TFTA has the potential to be an initiative with the broadest regional economic impact globally (United Nations Conference on Trade and Development [UNCTAD] 2017). The TFTA will merge three of Africa's existing RECs: the Common Market for Eastern and Southern Africa (COMESA), the East African Community (EAC) and the Southern African Development Community (SADC). The main objective of the COMESA-EAC-SADC tripartite agreement is to strengthen and deepen economic

1.Only eight of the 14 RECS are recognised by the African Union (AU): Common Market for Eastern and Southern Africa (COMESÄ) Community of Sahel-Saharan States (CEN-SAD), East African Community (EAC), Economic Community of Central African States (ECCAS), Economic Community of West African States (ECOWAS), Intergovernmental Authority on Development (IGAD), Southern African Development Community (SADC) and Arab Maghreb Union (UMA). 
integration in southern and eastern Africa by improving terms of trade, boosting infrastructure development and industrial growth, and addressing overlapping memberships among the RECs (Luke \& Mabuza 2015).

However, realising an ambitious Free Trade Agreement (FTA), like the TFTA, is a multidimensional challenge. Building new infrastructure, confronting issues associated with overlapping memberships and streamlining regulations, customs and border procedures can be a lengthy process. Nonetheless, something needs to be done in the meantime to drive intraAfrican trade. As outlined in the literature review, previous studies on the TFTA focused mostly on the impact and significance of the agreement for its member countries on a macroeconomic and sectoral level. This article however identifies, on a disaggregated product level, unexploited intraregional trade opportunities that serve as low-hanging fruit for exporters and trade promotion entities to start exploring. This can potentially help policymakers to adopt a more practical approach in promoting intra-regional trade in Africa.

This article reports these intra-regional trade opportunities on an importer-product-exporter level in the TFTA region. We first outline the main elements of regional trade theory, the motivations for deeper integration and the status of economic partnerships and competitiveness in Africa. We then discuss our method in which filter 2 of the Decision Support Model (DSM) (Cuyvers, Steenkamp \& Viviers 2012) is used, a market selection tool, applied for five consecutive years to identify consistently large and growing import demand potential in different TFTA countries. The export supply side is added to the model by evaluating the export capacity of the different countries, also over a fiveyear period. The import demand and export supply are then matched to arrive at export country-product-import country combinations (referred to as matches) with regional trade potential. The use of this regional trade potential then is evaluated by considering actual exports between the identified importing and exporting counties over the period 2010-2014.

We identified a total of 334 matches among the 26 TFTA countries, from which $232(70 \%)$ were newly recognised matched opportunities that are not being exploited at all. The top three product categories identified in these matches include foodstuffs, vegetable products and metals.

This analytical approach is unique for this purpose as it is applied within a regional context where 26 countries' import demand and export supply are considered and clearly demonstrates the opportunities for increased intra-regional trade within Africa.

\section{Literature review}

A brief review of the literature establishes the theoretical foundation of this article and consists of regional trade theories and the motivation for closer integration in Africa.

\section{Regional trade theories}

Although Africa's integration path has not been easy, there has been a series of initiatives and political decision-making to try and drive Africa's regional trade and integration efforts. This is embedded in the theoretical literature, with the biggest benefits expected to be gained from enlarged markets (United Nations Economic Commission for Africa [UNECA] 2012). This section provides an overview of the regional trade theories as a perspective on the potential gains from the proposed TFTA.

The literature on regional economic integration dates back to 1950 when Viner (1950) suggested that the effects of regional trade could be classified as static or dynamic; static effects can be either trade creating or trade diverting.

Trade creation occurs when countries give up the production of goods and services that their partner countries can produce more efficiently and cost-effectively. Integration will therefore stimulate new trade flows that will replace high-cost domestic production with lower-cost production in a partner country. This results in enhanced global and regional welfare. According to Robson (1994), trade creation is more likely if there are a large number of member countries, reduced tariffs and non-tariff barriers (NTBs) and the countries involved in the integration have similar levels of development and competitiveness.

The trade diversion effect, in contrast, reduces the welfare effect and is seen as a cost to the region. Trade is said to be diverted when imports shift away from more efficient, lowercost products and services towards more inefficient and expensive goods and services from regional partners. Trade diversion could lead to a loss of consumer surplus and make markets uncompetitive and inefficient (UNECA 2012).

If Africa's FTAs focused solely on lowering the barriers to intra-African trade, there is a danger that the costs of trade diversion would outweigh the benefits of trade creation. Through a liberal-regionalism approach of having a regional economic culture that respects the views and opinions of the member countries, African countries could be able to minimise the scope of trade diversion and maximise the benefits of trade creation (Keane 2016).

In contrast, dynamic effects focus on the impact of the regional trade agreement (RTA) on the rate of output growth of countries in the medium to long term. These effects are often the result of economies of scale because of enlarged markets, efficiency gains to more competitive markets, the removal of trade barriers and increased investments (UNECA 2012). De Melo, Panagariya and Rodrik (1993) argue that the most important economic gains are those that result from more affordable unit costs prompted by economic cooperation and policy coordination. In addition, De Melo et al. (1993) further argue that where regional groupings result in specialisation in accordance with comparative advantage and economies of scale, costs are reduced and welfare is improved. 
According to Maruping (2005), an expanded market is one of the most general outcomes of an RTA with increased access to the markets of member countries. These expanded market opportunities allow firms to specialise in the production of goods and services that were not viable before the integration. Moreover, Perdikis (2007) avers that an enlarged market creates greater competition between producers in member countries. Increased competition drives down prices and encourages firms to reduce expenses and use inputs more efficiently.

Various studies (Burfisher, Robinson \& Thierfelder 2004; Lawrence 1997; Sheer 1981; UNCTAD 2007) have referred to the static effects of Viner's theory as old regionalism, while the dynamic effects present the new regionalism. New regional integration theories have developed with changing economic conditions and are based on the idea that one cannot isolate trade from the rest of society. According to Lawrence (1997), the forces that drove earlier integration have changed drastically over the years. Old regionalism had a narrow focus on FTAs, with government as the pre-eminent actor, mainly focusing on extending import substitution and industrialisation strategies. New regionalism on the other hand is geared towards structural reforms to assist in making economies more open to implement export-orientated policies, market driven, competitive and democratic. Table 1 summarises the main differences in the driving forces of old and new regionalism.

Numerous studies have suggested that the emphasis should be on dynamic rather than on static effects when evaluating the appeal of integration among developing countries (Abdel 1971; Sakamoto 1969). In addition, Rueda-Junquera (2006) argues that the static effects of integration have little scope in benefits for developing countries and that the basic rationale for economic integration among developing countries should be a dynamic one.

Furthermore, Demas (1965) and Abdel (1971) claim that traditional economic integration theory relies strongly on neoclassical assumptions of perfect competition, full employment and constant returns to scale and, therefore, is limited to static effects of integration. In addition, Mikesell (1963) concludes that dynamic effects of integration are far more important than static effects because dynamic effects may lead to the exploitation of unused economic capacities and higher growth. According to UNECA (2012), the dynamic effects of FTAs in Africa could provide a better environment for industrial diversification and regional integration than each country could do on its own.

TABLE 1: Lawrence's comparison of old and new regionalism.

\begin{tabular}{ll}
\hline Old regionalism & New regionalism \\
\hline Import substitution & Export orientated \\
Planned allocation resources & Market allocation of resources \\
Led by government & Led by private firms \\
Mainly industrial products & All goods, services and investments \\
\hline
\end{tabular}

Source: Lawrence, R.Z., 1997, 'Preferential trading arrangements: The traditional and the new', in A. Galal \& B. Hoekman (eds.), Regional partners in global markets: Limits and
possibilities of the Euro-Med agreements, chapter 2, pp. 19, Center for Economic Policy Research (CEPR) and the Egyptian Center for Economic Studies (ECES), Cairo.
Unfortunately, Africa's current intra-regional trade is still modest - the continent trades mostly with the world's most advanced economies like the United States, United Kingdom and China. African countries will not be able to exploit the full benefits to be expected from the TFTA until policymakers address the barriers that prohibit the movement of goods within their own borders.

\section{Africa's integration and competitiveness record}

Africa's integration agenda, laid down in documents such as the Abuja Treaty and the African Union's Agenda for 2063, has been very ambitious. African leaders have been clear about their aspirations to build a continent where goods and services could be traded freely across borders, world-class infrastructure would connect countries and policies would be harmonised. However, turning this vision into a reality has proved particularly challenging.

The concept of a FTA and its role in refining regional trade integration originated from the Abuja Treaty which seeks to use RECs as building blocks of regional integration and economic development in Africa. COMMESA, EAC and SADC will bring together 26 southern and eastern African countries, which will form the TFTA. These include Angola, Botswana, Burundi, Comoros, Djibouti, Democratic Republic of the Congo, Egypt, Eritrea, Ethiopia, Kenya, Lesotho, Libya, Madagascar, Malawi, Mauritius, Mozambique, Namibia, Rwanda, Seychelles, South Africa, Sudan, Swaziland, Tanzania, Uganda, Zambia and Zimbabwe.

However, there is a consensus that the existing RECs have had little success in driving intra-African growth. Consequently, one of the main challenges that policymakers will face to make the envisioned TFTA work better than the existing trade regimes is how to address the obstacles to intra-African trade. These include restrictive NTBs, rules of origin, high transport costs, border inefficiencies and behind-the-border costs, to name but a few (World Bank 2015). Although some of Africa's RECs have made progress in some areas of integration, many still lag behind.

To elaborate further on the continent's efforts at integration, the African Regional Integration Index Report compiled by the African Union Commission (AUC), the African Development Bank (AfDB) and the Economic Commission for Africa (ECA) (UNECA 2016) measures RECs' level of regional integration and their progress towards implementing their commitment under their respective integration frameworks. The index shows results for eight of Africa's biggest RECs, namely CEN-SAD, COMESA, EAC, ECCAS, ECOWAS, IGAD, SADC and the Arab Maghreb Union (UMA). For the purpose of this study, only the results of COMESA, EAC and SADC are considered.

The index is made up of five key socio-economic categories (dimensions) - regional infrastructure, trade integration, 
productive integration, free movement of people, and financial and macroeconomic integration - that are crucial to Africa's integration agenda. Each dimension has its respective subcomponents as illustrated in Figure 1. These dimensions are based on the operational framework of the Abuja Treaty.

Table 2 summarises the scores that each of the RECs in the TFTA obtained under the different dimensions. Scores are calculated on a scale of 0 (low) to 1 (high), with the overall average score for regional integration in Africa standing at 0.470 .

On a country level, in COMESA, Egypt was the top contributor to wealth creation in the region (with a source of $35 \%$ of COMESA's GDP), but was ranked fourth on regional integration. Sudan and Libya are the second and third contributors to wealth creation in COMESA, although they are not top performers with respect to integration. In the EAC, Kenya and Uganda are the top contributors to wealth creation ( $39 \%$ and $21 \%$ of regional GDP). The EAC is the region with the best performance in the trade integration dimension. Finally, in SADC, South Africa represents $61 \%$ of regional GDP and ranks first in the overall integration index. The EAC is the top performing REC in terms of trade integration (0.78), followed by COMESA (0.572).
It is important, however, to keep in mind that the scope and development of the integration process in the three RECs are different. Each REC implements separate regional trade programmes, infrastructure development and economic development programmes. Streamlining these programmes should therefore be a priority in realising the objectives of the TFTA. Furthermore, most of the countries in the TFTA belong to more than one of the RECs. Of COMESA's 19 members, eight are also members of SADC and four are members of the EAC. The EAC has five members, one of which is a member of SADC and four are members of COMESA. In SADC, 8 of the 15 members are also members of COMESA and one is a member of EAC. These overlapping memberships have contributed to the difficulty of fully implementing trade agreements.

Furthermore, Africa's share of intra-regional trade compares unfavourably with other regions of the world. Only about $16 \%$ of Africa's total trade is with other African countries, whereas the corresponding figures for Europe, Asia and America are 68\%, 59\% and 55\% (UNCTAD 2019). Also, Africa's RECs have a low share of intra-group trade relative to other regional groups in the world. The top 14 worldwide regional groupings have an average of $42 \%$ intra-group trade compared to Africa's 10\% (UNCTAD 2017).

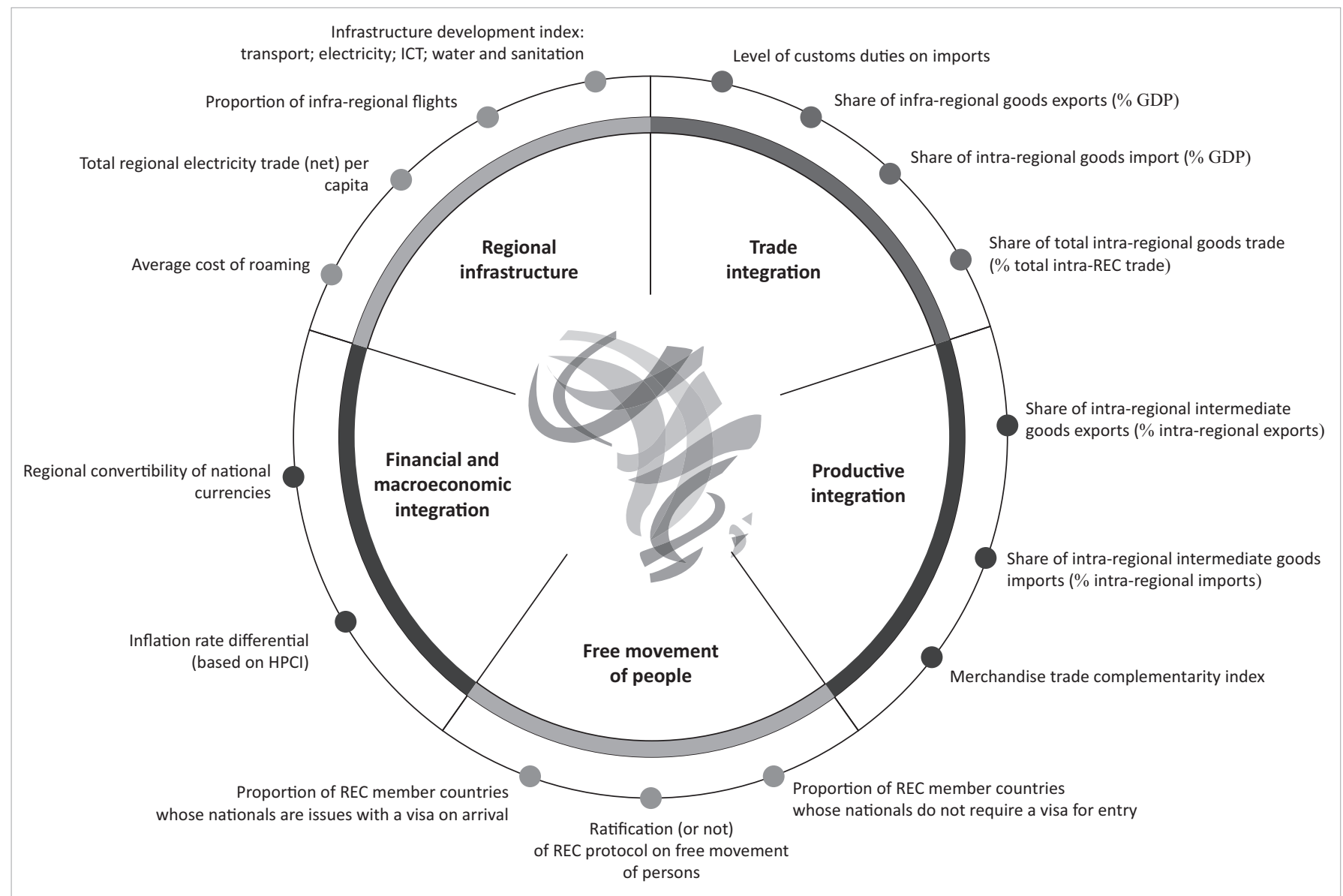

Source: African Development Bank (AfDB), African Union Commission (AUC) \& United Nations Economic Commission for Africa (ECA), 2016, The Africa Regional Integration Index: 2016 Report, viewed 15 May 2017, from https://www.uneca.org/publications/africa-regional-integration-index-report-2016

$\mathrm{HPCl}$, harmonised consumer price indices.

FIGURE 1: African regional integration index: The five dimensions. 
TABLE 2: Summary of the African Regional Integration Index Report scores for Common Market for Eastern and Southern Africa, the East African Community and the Southern African Development Community.

\begin{tabular}{lcccc}
\hline RECs & Trade integration & $\begin{array}{c}\text { Regional } \\
\text { infrastructure }\end{array}$ & $\begin{array}{c}\text { Productive } \\
\text { integration }\end{array}$ & $\begin{array}{c}\text { Free movement } \\
\text { of people }\end{array}$ \\
\hline COMESA & 0.572 & 0.439 & 0.452 & 0.268 \\
EAC & 0.780 & 0.496 & 0.553 & 0.343 \\
SADC & 0.508 & 0.502 & 0.350 & 0.156 \\
Average for COMESA, EAC and SADC & $\mathbf{0 . 6 2}$ & $\mathbf{0 . 4 7 9}$ & $\mathbf{0 . 4 5 1}$ & 0.530 \\
\hline
\end{tabular}

Source: Compiled from the African Regional Integration Index Report, United Nations Economic Commission for Africa (UNECA), 2016, Africa regional integration index, viewed 12 July 2017, from https://www.uneca.org/publications/africa-regional-integration-index-report-2016

REC, regional economic communities; COMESA, Common Market for Eastern and Southern Africa; EAC, the East African Community; SADC, the Southern African Development Community

The TFTA, if properly implemented, could have a substantial impact on the current low levels of intra-regional trade.

\section{Studies investigating the impact of the Tripartite Free Trade Agreement}

A number of studies have investigated whether, and to what extent, the establishment of the TFTA specifically can be expected to create new opportunities for its member countries. Inama and Crivelli (2014) explored whether the TFTA can deliver effective and real trade liberalisation for economic growth. Their findings showed a substantial increase in trade creation, despite low levels of export diversification, the small number of traded products and the low share of trade in manufactured products. GarlinskaBielawska (2016) investigated the potential economic benefits of the TFTA for the three regional formations COMESA, EAC and SADC - and found that, in theory, economic gains are expected; however, whether it will be realised depends on factors such as complementarity between member countries, infrastructure and willingness to pursue integration opportunities. In addition, Babatunde and Odularu (2017) focused on lessons and policy directions for the TFTA, stating that the three RECs will need to focus their efforts on key areas such as competition policy, technical barriers, electronic commerce, rules of origin and dispute settlement.

Numerous studies have also modelled the potential impact of the TFTA on the participating countries and found substantial increase in trade among member countries, increased industrial production, employment and welfare gains (Mold \& Mukwaya 2017; Willenbockel 2013; Walters, Bohlmann \& Clance 2016). However, none of these studies has considered a product-level demand-supply approach for identifying specific untapped potential trade opportunities within the region.

To summarise, despite the potential benefits of regional trade, there are many obstacles and challenges to intraAfrican trade threatening the success of the TFTA. Addressing these challenges can be a lengthy process. For example, building new infrastructure, disentangling overlapping REC memberships and renegotiating in the face of political agendas and increasing tendency towards protectionism all take time. In the meantime, this article addresses the issue of low intra-regional trade by identifying potential trade opportunities among the TFTA countries. This product-level supply-and-demand approach highlights low-hanging fruit for exporters and trade promotion entities to investigate and pursue - it provides a shorter-term, interim, proactive approach to start addressing the problem of low intraregional trade.

The next section describes the research method applied in this study to identify specific importer-product-exporter combinations (referred to as matches) with intra-regional trade potential within the 26 TFTA countries. This contributes what we believe is useful information on how to promote intra-regional trade among these countries, providing a product-level intra-regional trade opportunity analysis.

\section{Research method}

The research method includes a process in which, firstly, the import demand for different products was evaluated within all 26 TFTA countries. Secondly, the export supply for all possible product and country combinations was assessed. These analyses enable the matching of consistently large and growing import demand and competitive export supply within the TFTA countries. Each match that was identified formed an intra-regional trade opportunity. Finally, the exploitation of these intra-regional trade opportunities was evaluated.

\section{Determining consistently large and growing import demand}

Filter 2 of the DSM, developed by Cuyvers, De Pelsmacker, Rayp and Roozen (1995), Cuyvers (1997) and Cuyvers et al. (2012), was applied in this article to evaluate the import demand within the TFTA region on the international Harmonised System (HS) six-digit level. The DSM uses a focused approach to export promotion by identifying and prioritising export opportunities. It is currently the only market selection tool found in the literature that uses a filtering process that sifts through an extensive range of country and product data to identify product-country combinations, or export opportunities for trade.

To determine in which products the TFTA countries showed sufficient short-term and long-term growth, as well as sufficient import market size, import data per productcountry combination at an HS six-digit level were used. The trade data (import and export) were obtained from the 
CEPII BACI ${ }^{2}$ database for 2010-2014. It is important to note that the CEPII BACI data are audited, meaning that the import value is equal to the export value for the same importer, exporter and product. ${ }^{3}$ However, CEPII reports the trade in the Southern African Customs Union (SACU) as one combined value in its BACI database; it therefore does not report trade data for South Africa, Botswana, Lesotho, Namibia and Swaziland separately. In this study, however, it is important to work with the individual country values. The CEPII BACI import total for the SACU was therefore split between the member countries in the proportions of the reported import values in the UN COMTRADE data $^{4}$, in which trade data are reported separately for the five SACU member countries. ${ }^{5}$

Short-term growth was calculated by measuring the growth in imports from 2013 to 2014 . The long-term growth rate was calculated as the compounded annual percentage growth in the imports over the five-year period from 2010 to 2014. The import value indicates the size of import demand in each market.

To determine which product-country combinations showed satisfactory size and growth, cut-off criteria had to be set. In defining cut-off values for import size and growth, Cuyvers et al. (1995), Cuyvers (2004) and Cuyvers et al. (2012) first calculated a scaling factor $\left(\mathrm{s}_{\mathrm{j}}\right)$ to take into account the degree of specialisation of the exporting country in each product $j$. The model defines the scaling factor as follows (Balassa 1965; Cuyvers et al. 1995):

$$
\begin{aligned}
& s j=0.8+\frac{1}{(R C A J+0.085) \exp ^{\left(R C A_{j}-0.01\right)}} \\
& \text { where } R C A j=\left(\frac{X n, j}{X W, j}\right) /\left(\frac{X n, t o t}{X W, t o t}\right)
\end{aligned}
$$

- $X_{n, j}$ : exports of country $n$ of product $j$;

- $X_{W, j}$ : worldwide exports of product $j$;

- $X_{n, t o t}$ : total exports of country $n$;

- $X_{W, t o t}:$ worldwide exports of all product categories.

Cuyvers (2004) considers a market sufficient in import growth if:

$$
g_{i j} \geq G_{j}
$$

2.BACI is a trade database, developed by the centre d'Études Prospectives et d'Informations Internationales (CEPII) which is a French institute doing research into d'Informations Internationales (CEPI) which is a French institute doing research int international economics, providing bilateral trade flows for more than 5000 product and 200 countries. The database is built from data reported to the United Nations Statistical Division (UN COMTRADE) and reconciles the trade values reported by exporters and importers (CEPII, 2020).

3.Exports are reported free on board (FOB) and imports cost, insurance and freight (CIF). This is why the import and export values for the same exporter-importerproduct combination differ in the UN COMTRADE data set.

4.UN COMTRADE is the pseudonym for United Nations International Trade Statistics Database.

5.CEPII BACI SACU import total for product 10190 (live horses other than pure-bred breeding animals) is USD 4670684 . In the UN COMTRADE data set, Botswana imports USD 354 450, Lesotho USD 1527 948, Namibia USD 992 933, South Africa USD 1644088 and Swaziland USD 0. The proportions are, therefore, Botswana = $7.589 \%$, Namibia $=21.259 \%$, Lesotho $=32.714$ and South Africa $=35.2 \%$. These proportions are multiplied by the BACI SACU total to arrive at a comparable value per SACU country. where $g_{i j}$ is the import growth rate of product $j$ by importing country $i$; and the cut-off value $G_{j}$ is defined as:

$G_{j}=g_{w, j} s_{j}$, if $g_{w^{\prime} j} \geq 0$; or

$G_{i}=g_{w, j} / s_{j}$, if $g_{w,}<0$

[Eqn 4]

where $g_{w, j}$ is the average world import growth rate for product $j$.

The DSM is normally applied from a specific exporting country's point of view. However, in the case of this study, there are 26 TFTA countries that needed consideration. Because we consider only products in which the exporting country has a revealed competitive advantage (RCA) greater than or equal to 1 , an RCA value of 1 was used in the calculation of the scaling factor for all products and countries under consideration. A scaling factor of 1.000852 was therefore used throughout.

This implies that if a particular country's import growth for a product is equal to or greater than the average world import growth rate for the product, it can be considered a market with sufficient import growth.

Cuyvers (2004) considers the import market of country $i$ for product $j$ large enough if:

$M_{i, j} \geq S_{j}$

where $M_{i, j}$ is the importing country $i$ for product category $j$; and the cut-off value $S_{j}$ is defined as:

$S_{j}=0.02 M_{w, j}$, if $R C A_{j} \geq 1$; or

$s_{j}=\left[\frac{\left(3-R C A_{j}\right)}{100}\right] M_{w, j}, i f R C A_{j}<1$

where $M_{W, j}$ is the total world import value for product $j$.

Because we consider only products and country combinations for which the exporter has an RCA greater than or equal to 1, a particular country's import size for a product is considered sufficiently large if this import value is equal to or greater than $2 \%$ of the total world imports of the product.

The DSM considers the import data for each product in the 26 TFTA countries to determine whether the countries showed sufficient short-term and long-term growth and import market size. Only country-product combinations that passed the criteria for short-term import growth, long-term import growth, as well as import market size for five consecutive years were considered as markets with consistently large and growing import demand in this study. The traditional DSM applications consider import size and growth at only one point in time (Cuyvers et al. 2017; Mhonyera, Steenkamp \& Matthee 2018); however, this study repeated filter 2 of the DSM for five consecutive years. 


\section{Determining consistently competitive export supply}

The export supply was added to the DSM by evaluating the export capacity of the different countries over the period 2010-2014.

The RCA of Balassa (1965) was used to determine the export capacity of the different TFTA product-country combinations under consideration. The RCA represents the relative specialisation of a country in the production of a specific product by dividing the product's export share of the country's total exports by its share in world exports (Jessen \& Vignoles 2004). Thus, it indicates whether a country has the ability to produce and exporta particular productcompetitively. This article uses the RCA to indicate the supply capacity of the different TFTA countries.

The supply country also had to meet the criteria of an RCA greater than or equal to 1 for each year of the five-year period 2010-2014 in order to be selected as a consistent exporter of a product.

Note that a similar calculation was performed on the SACU export data as for the import data, to separate out the values for each of the member countries from the CEPII BACI data in the proportions calculated from the UN COMTRADE data as explained in the previous section.

The import demand and export supply were then matched to arrive at importer-product-exporter combinations (referred to as matches) with regional trade potential. This is a unique approach as this study does not only consider one exporting country's point of view. The exploitation of this regional trade potential was then evaluated by considering actual exports over the same period.

\section{Evaluating the current exploitation of the identified trade opportunities}

To arrive at the export country-product-import country combinations $^{6}$ with regional trade potential, the import demand and export supply were matched. In order to distinguish between existing and new matches, the intraregional trade opportunities were classified into four categories: increase, decline, extinct (now abandoned) and zero. This was done by calculating how the values of existing exports changed between 2010 and 2014.

The UN COMTRADE data were used to determine these trends in existing trade flows. This is because it is not possible to derive bilateral trade among SACU members on a detailed product level from the CEPII BACI data. However, to compare and verify the trend in the UN COMTRADE data for each SACU and non-SACU match, an export value was calculated from the CEPII BACI data in a similar way as 6.Interchangeably referred to as intra-regional trade opportunities, or matches, in this study. explained in the previous section. Also, the trend in the UN COMTRADE mirror data was used to further verify the corresponding trend.

\section{Results}

\section{Potential export opportunity matches among the Tripartite Free Trade Agreement countries}

The proposed TFTA has clearly set high goals and expectations for regional trade integration. However, Africa's slow trade integration shows that the process has thus far not produced the results policymakers were hoping for. This article has identified specific trade opportunities among the 26 TFTA countries, which can be seen as priorities and starting points for increasing intra-regional trade.

Table 4 indicates the importer-product-exporter combinations identified according to HS2 level product categories. A total of 334 matches were identified among the 26 TFTA countries. From these, only $74(22 \%)$ indicated a bilateral trade relationship that already exists and has increased over time. Seventeen matches $(5 \%)$ showed a decline in trade and $11(3 \%)$ have become extinct. This left a substantial number of $232(70 \%)$ newly recognised matched opportunities between TFTA countries that are not being exploited at all. Thus, $78 \%$ of the matched intra-regional trade opportunities are underexploited or unexploited.

The top five product categories for the 334 intra-regional trade opportunities identified among the TFTA countries are: (1) vegetable products (mostly primary food and beverages including beans, fresh fruit, maize flour, wheat flour and

TABLE 3: Categories of utilisation.

\begin{tabular}{lll}
\hline Category & Trade value specification & Description \\
\hline Increase & Value $2014>$ Value 2010 & Increase in existing trade flows \\
Decline & Value $2014<$ Value 2010 & Decrease in existing trade flows \\
Extinct & Value $2010>0$ \& Value $2014=0$ & The relationship has become extinct \\
Zero & Trade $=0$ & No trade relationship \\
\hline
\end{tabular}

Source: Matthee, M., Idsardi, E. \& Krugell, W., 2015, 'Can South Africa sustain and diversify its exports?', South African Journal of Economic and Management Sciences 19(2), 255. https://doi.org/10.4102/sajems.v19i2.1324

TABLE 4: Number of matches identified according to product categories.

\begin{tabular}{lccccc}
\hline HS2 product category & \multicolumn{7}{c}{ Total } & Increase & Decrease & Extinct & Zero \\
\hline (HS01-HS05) Animal and animal products & 17 & 6 & 1 & 1 & 9 \\
(HS06-HS15) Vegetable products & 95 & 23 & 1 & 1 & 70 \\
(HS16-HS24) Foodstuffs & 49 & 12 & 5 & 3 & 29 \\
(HS25-HS27) Minerals & 10 & 2 & 0 & 1 & 7 \\
(HS28-HS38) Chemicals and allied & 14 & 2 & 2 & 1 & 9 \\
industries & & & & & \\
(HS39-HS40) Pharmaceuticals & 3 & 0 & 0 & 0 & 3 \\
(HS41-HS43) Raw hides, skins, leather & 4 & 2 & 0 & 0 & 2 \\
and fur & & & & & \\
(HS44-HS49) Wood and wood products & 13 & 2 & 1 & 0 & 10 \\
(HS50-HS63) Textiles & 39 & 2 & 0 & 2 & 35 \\
(HS64-HS71) Stone/glass & 14 & 3 & 0 & 0 & 11 \\
(HS72-HS83) Metals & 45 & 14 & 5 & 0 & 26 \\
(HS84-HS85) Machinery/electrical & 12 & 2 & 1 & 0 & 9 \\
(HS86-HS89) Transportation & 12 & 4 & 1 & 0 & 7 \\
(HS90-HS97) Miscellaneous & 7 & 0 & 0 & 2 & 5 \\
\hline Total & $\mathbf{3 3 4}$ & $\mathbf{7 4}$ & $\mathbf{1 7}$ & $\mathbf{1 1}$ & $\mathbf{2 3 2}$ \\
\hline
\end{tabular}


soya bean oil), (2) foodstuffs (mostly processed food and beverages including cereals, sausages, preserved fruit and vegetables), (3) metals (mostly processed industrial supplies including steel, iron and copper pipes, bars, rods, tubes, wire, sheeting, sanitary ware and drilling tools), (4) textiles (including clothes, kitchen linen, sacks and bags) and (5) animal and animal products (including mostly processed products such as frozen fish and cheese). In comparison, the top five product categories for the 232 newly matched opportunities include: (1) vegetable products, (2) textiles, (3) foodstuffs, (4) metals and (5) stone and glass (including processed industrial supplies such as ceramic tiles, sinks, basins, baths and imitation jewellery).

Figure 2 distinguishes the trade corresponding to the matches derived in terms of the categories of utilisation (see Table 5). Although some of the opportunities are being exploited, it is clear that most are underexploited or unexploited. The figure also summarises the results of the opportunities identified according to HS2 level product categories, with the greatest demand being for vegetable products, foodstuffs, textiles and metals.

Tables 5-8 illustrate the specific intra-regional trade opportunities between the TFTA countries on an importerproduct-exporter level. These tables show the top matches ranked according to weighted import demand divided into the four categories of utilisation listed in Table 5. Each year (in the period 2010-2014) was assigned a weight to calculate the weighted average ${ }^{7}$ and these measures determined the relative importance of the trade values reported in each year, giving an indication of the size of the total import demand in each market. A larger weight was assigned to more recent trade figures to place more emphasis on the latest trade (Cuyvers et al. 2017).

Table 5 shows the top 20 matches (a selection of the total of 74 opportunities for illustrative purposes) that are being exploited, which indicates an increase in trade between 2010 and 2014.

Considering the number of opportunities in importing countries, Angola has the most opportunities (13), followed by Mozambique (9), Zambia (9) and Zimbabwe (8). On the supply side, South Africa and Egypt are the biggest suppliers among the 74 matches with an increase in trade, supplying more than half of the goods demanded. According to the harmonised commodity description and coding systems (HS), these goods include mainly vegetable products and metals. In terms of the broad economic categories (BECs), $32 \%$ are primary products, whereas $68 \%$ are processed

7. Weighted average import value $=(2014$ import value $\times 1)+(2013$ import value $\times 0.5)$ $+(2012$ import value $\times 0.25)+(2011$ import value $\times 0.125)+(2010$ import value $\times$ $0.0625) / 1.9375$

8.The broad economic categories (BECS) were created by the United Nations Department of Economic and Social Affairs. The BECS are defined in terms of the divisions, groups, subgroups and basic headings of the Standard International Trade divisions, groups, subgroups and basic headings of the Standard International Trade Classification that was issued in 1971; it has since been revised three times; United Nations, Classification by broad economic categories, https://unstats.un.org/unsd/ $\mathrm{cr} /$ registry/regdnld.asp? Lg=1. products. Most of the regional trade opportunities identified with an increase in actual trade are between countries representing COMESA and SADC.

Table 6 illustrates all 17 matches that showed a decline in trade between 2010 and 2014, meaning that there is consistently large and growing import demand that can be satisfied with a consistently competitive export supply. However, actual trade has declined over this period. The greatest declines were in the machinery, electrical, metals and transportation sectors. Only one of the opportunities identified was for a primary product (namely seeds); the rest are categorised in the BECs as processed goods. According to UNCTAD (2007), African countries have been experiencing significant deindustrialisation since the 1990s, resulting in a decline in both intra-regional and global trade over the past two decades.

Table 7 shows the 11 matches where there is no longer any trade. According to the BECs, only two of the opportunities that became extinct are in primary goods (namely spices and cobalt ores). The others involve some form of processing. It is worth noting that the importing countries have a large and growing import demand for the products listed and that exporting countries can supply them as reflected in their export data for the product, yet trade between these TFTA countries for the products listed has stopped. Further investigation into the reasons for this is necessary.

Table 8 shows the top 20 matched trade opportunities (a selection from the 232 matches for illustration) within the TFTA that are not being utilised. This implies that even though the importing country has a consistently large and growing import demand for the corresponding product and the exporting country is a specialist exporter of these goods, there has been no trade between the countries involved for these particular products over the period 2010-2014. The importing country, therefore, is sourcing this product from other suppliers, whereas they could have received it from within the region.

Considering all 232 unexploited matched trade opportunities on a country level, Angola has 60 unexploited trade opportunities, followed by Mozambique with 28 opportunities and Egypt with 23. The supplying countries with the largest number of unexploited potential for their products include Botswana (45), Egypt (37), Lesotho (37) and Mauritius (31).

To integrate the results presented in Tables 5-8, the following examples from the results for Angola are presented. There are 76 opportunities in total in Angola of which 13 (17\%) are utilised, three show a decline in actual trade and $60(79 \%)$ are totally unexploited by other TFTA countries. Although Egypt utilises (at least to some extent) the export potential in Angola for wheat flour, toilet paper, preserved potatoes, lemons and limes, and articles of nickel, it loses out on fresh fruit, soya 


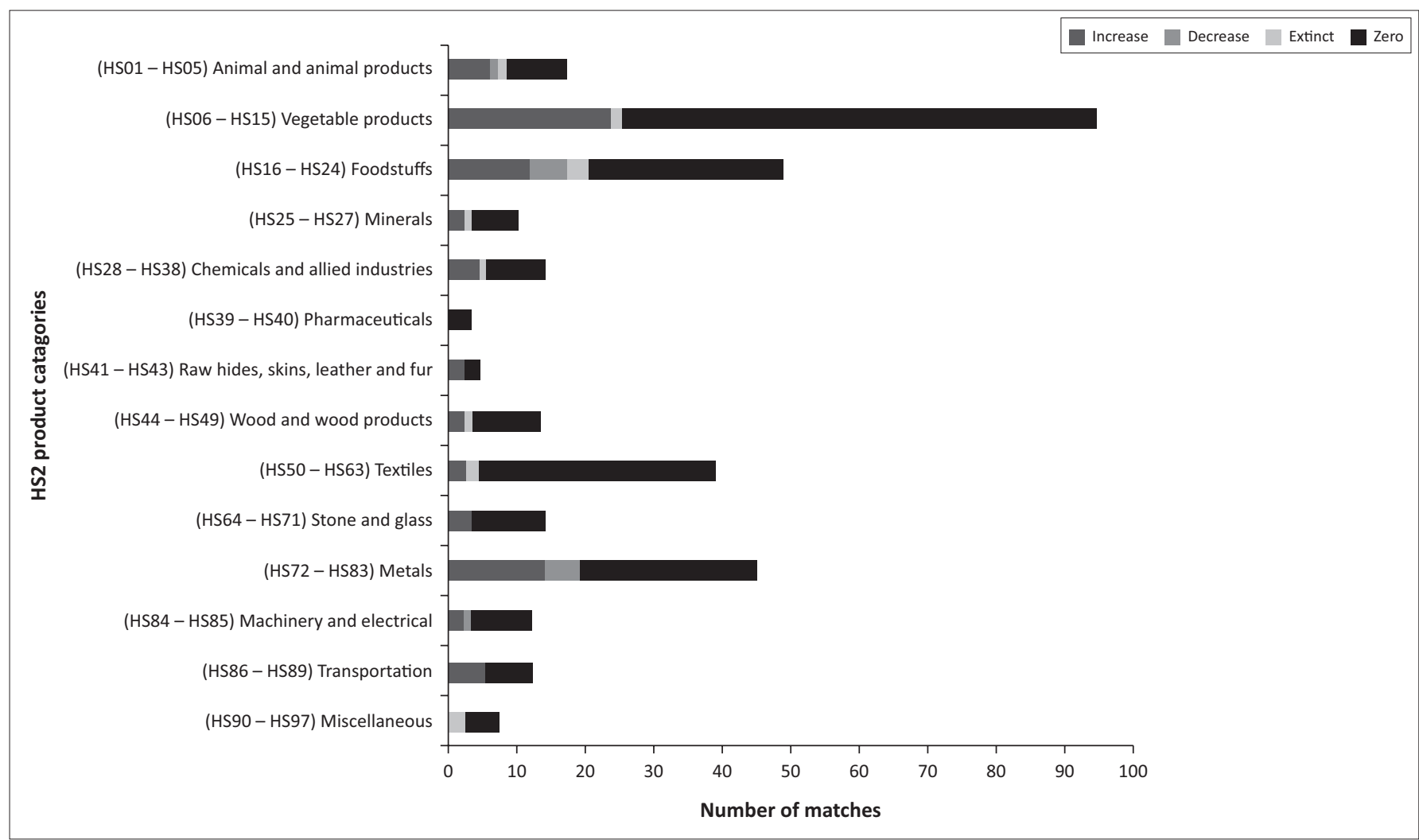

FIGURE 2: Tripartite Free Trade Agreement intra-regional trade opportunities: Product category analysis.

TABLE 5: Top 20 importer-product-exporter matches with an increase in trade: 2010-2014.

\begin{tabular}{|c|c|c|c|c|}
\hline Importer & $\begin{array}{l}\text { Product code } \\
\text { (HS6 digit-level) }\end{array}$ & Product description & Exporter & $\begin{array}{l}\text { Weighted average } \\
\text { import value }\left(\$^{\prime} 000\right)\end{array}$ \\
\hline Angola & 110100 & Wheat or meslin flour & Egypt & 218712 \\
\hline Libya & 40630 & Processed cheese, not grated or powdered & Egypt & 98927 \\
\hline Egypt & 71350 & $\begin{array}{l}\text { Broad beans (Vicia faba var. major) and horse beans (Vicia faba var. equine and Vicia faba var. minor), } \\
\text { shelled, whether or not skinned or split, dried }\end{array}$ & Ethiopia & 70587 \\
\hline Angola & 110220 & Cereal flour; of maize (corn) & South Africa & 60057 \\
\hline Angola & 110313 & Cereal groats and meal; of maize (corn) & South Africa & 44598 \\
\hline Tanzania & 871631 & Tanker trailers and tanker semi-trailers & South Africa & 32860 \\
\hline Libya & 690710 & $\begin{array}{l}\text { Unglazed ceramic tiles, cubes and similar articles; unglazed, whether or not rectangular, the largest } \\
\text { surface area of which is capable of being enclosed in a square of side less than } 7 \mathrm{~cm}\end{array}$ & Egypt & 28384 \\
\hline Angola & 121020 & Hop cones, fresh or dried, ground or powdered or in the form of pellets; lupulin & Namibia & 27753 \\
\hline Mozambique & 340220 & $\begin{array}{l}\text { Surface-active preparations, washing preparations, whether or not containing soap } \\
\text { (excluding those of heading no. 3401), put up for retail sale }\end{array}$ & Botswana & 19304 \\
\hline Libya & 200570 & Olives, prepared or preserved other than by vinegar or acetic acid, not frozen & Egypt & 17788 \\
\hline Congo & 870421 & $\begin{array}{l}\text { Motor vehicles for the transport of goods (of a gross vehicle weight not exceeding } 5 \text { tonnes), not } \\
\text { elsewhere specified in item no } 8704.1\end{array}$ & Botswana & 17141 \\
\hline South Africa & 740400 & Copper waste and scrap & Namibia & 13624 \\
\hline Uganda & 170410 & Chewing gum, whether or not sugar-coated & Kenya & 10642 \\
\hline Angola & 481810 & Toilet paper, in rolls of a width not exceeding $36 \mathrm{~cm}$ or cut into size or shape & Egypt & 9648 \\
\hline Egypt & 80940 & Plums and sloes, fresh & South Africa & 9304 \\
\hline Mozambique & 440310 & $\begin{array}{l}\text { Wood, in the rough, whether or not stripped of bark or sapwood or roughly squared, treated with } \\
\text { paint stains, creosote or other preservatives }\end{array}$ & Swaziland & 7868 \\
\hline Zambia & 210390 & Sauces and preparations; mixed condiments and mixed seasonings & Botswana & 7559 \\
\hline Zambia & 210390 & Sauces and preparations; mixed condiments and mixed seasonings & Kenya & 7559 \\
\hline Zimbabwe & 210390 & Sauces and preparations; mixed condiments and mixed seasonings & Kenya & 7559 \\
\hline
\end{tabular}

bean oil, cereals, undenatured ethyl alcohol, men's clothing, table linen, as well as sacks and bags. Also, Namibia utilises (increased exports) the export potential in Angola in frozen fish other than fillets (liver or roes) and processed meat of bovines, but loses out on engine parts and frozen fish fillets (decrease in exports). Although South Africa utilises the export potential in Angola for maize meal, fresh fruit and flat-rolled stainless steel products, it loses out on dried fish (zero exports) and hair straightening or waving products (decrease in exports).

Coming back to the results for the 232 unexploited regional trade opportunities between the TFTA countries, the goods demanded include mostly vegetable products, foodstuffs, 
TABLE 6: Importer-product-exporter matches where trade has declined (2010-2014).

\begin{tabular}{|c|c|c|c|c|}
\hline Importer & $\begin{array}{l}\text { Product code } \\
\text { (HS6 digit-level) }\end{array}$ & Product description & Exporter & $\begin{array}{l}\text { Weighted average import } \\
\text { value ( } \$ \text { thousand) }\end{array}$ \\
\hline Angola & 840999 & Engines; parts for internal combustion piston engines (excluding spark-ignition) & Namibia & 47564 \\
\hline Egypt & 721990 & $\begin{array}{l}\text { Flat-rolled products of stainless steel, of a width of } 600 \mathrm{~mm} \text { or more, not elsewhere specified in } \\
\text { heading no. } 7219\end{array}$ & South Africa & 37219 \\
\hline Tanzania & 871631 & Tanker trailers and tanker semi-trailers & Kenya & 32860 \\
\hline South Africa & 230610 & $\begin{array}{l}\text { Oil-cake and other solid residues, whether or not ground or in pellets, from the extraction of } \\
\text { cotton seed oils }\end{array}$ & Zimbabwe & 28340 \\
\hline South Africa & 722880 & Hollow drill bars and rods of alloy and non-alloy steel & Botswana & 14042 \\
\hline Uganda & 170410 & Chewing gum, whether or not sugar-coated & Egypt & 10642 \\
\hline Angola & 330520 & Preparations for permanent waving or straightening the hair & South Africa & 9812 \\
\hline Angola & 030420 & Fish fillets, frozen & Namibia & 4650 \\
\hline Ethiopia & 722880 & Prepared glues and other prepared adhesives, not elsewhere specified in 35.06 & South Africa & 4124 \\
\hline Zimbabwe & 730490 & Tubes, pipes and hollow profiles, seamless, not elsewhere specified in heading 7304 & South Africa & 2999 \\
\hline Libya & 120999 & Seeds, not elsewhere specified, of a kind used for sowing & Egypt & 1305 \\
\hline South Africa & 200990 & $\begin{array}{l}\text { Mixtures of juices, unfermented and not containing added spirit, whether or not containing } \\
\text { added sugar or other sweetening matter }\end{array}$ & Botswana & 344 \\
\hline South Africa & 200990 & $\begin{array}{l}\text { Mixtures of juices, unfermented and not containing added spirit, whether or not containing } \\
\text { added sugar or other sweetening matter }\end{array}$ & Swaziland & 344 \\
\hline Zambia & 721934 & $\begin{array}{l}\text { Flat-rolled products of stainless steel, of a width of } 600 \mathrm{~mm} \text { or more, cold-rolled, of a thickness } \\
\text { of } 0.5 \mathrm{~mm} \text { or more but not exceeding } 1 \mathrm{~mm}\end{array}$ & South Africa & 217 \\
\hline Madagascar & 721924 & $\begin{array}{l}\text { Flat-rolled products of stainless steel, of a width of } 600 \mathrm{~mm} \text { or more, hot-rolled (not in coils), } \\
\text { of a thickness of less than } 3 \mathrm{~mm}\end{array}$ & South Africa & 56 \\
\hline
\end{tabular}

TABLE 7: Importer-product-exporter matches where trade has become extinct (2010-2014).

\begin{tabular}{|c|c|c|c|c|}
\hline Importer & $\begin{array}{l}\text { Product code } \\
\text { (HS6 digit-level) }\end{array}$ & Product description & Exporter & $\begin{array}{l}\text { Weighted average import } \\
\text { value (US\$ thousand) }\end{array}$ \\
\hline Zimbabwe & 260500 & Cobalt ores and concentrates & Congo & 87978 \\
\hline South Africa & 40630 & Processed cheese, not grated or powdered & Egypt & 15305 \\
\hline Mozambique & 940360 & Furniture; wooden, other than for office, kitchen or bedroom use & Egypt & 14211 \\
\hline Zimbabwe & 210390 & Sauces and preparations; mixed condiments and mixed seasonings & Botswana & 7559 \\
\hline South Africa & 210130 & Chicory, roasted and other roasted coffee substitutes; extracts, essences and concentrates & Botswana & 5104 \\
\hline Libya & 200510 & $\begin{array}{l}\text { Vegetable preparations; potatoes, prepared or preserved otherwise than by vinegar or acetic } \\
\text { acid, frozen }\end{array}$ & Egypt & 1456 \\
\hline Mozambique & 91099 & Spices, not elsewhere specified & Kenya & 1351 \\
\hline Tanzania & 950490 & $\begin{array}{l}\text { Articles for funfair, table and parlour games (excluding playing cards), including pintables, tables } \\
\text { for casino games, bowling alley equipment, not elsewhere specified }\end{array}$ & Kenya & 963 \\
\hline Zimbabwe & 610610 & Women's and girls' blouses, shirts and shirt-blouses, knitted or crocheted & Mauritius & 604 \\
\hline Zimbabwe & 610442 & Women's and girls' dresses, knitted or crocheted, of cotton & Mauritius & 253 \\
\hline Kenya & 380910 & $\begin{array}{l}\text { Finishing agents, dye carriers to accelerate the dyeing or fixing of dyestuffs, other products and } \\
\text { preparations, used in textile, paper and leather industries }\end{array}$ & Egypt & 72 \\
\hline
\end{tabular}

metals and textiles. According to the BECs, approximately $30 \%$ of the identified opportunities are in primary goods and $70 \%$ in processed goods, of which $56 \%$ are in household and consumer goods (see Figure 3).

Figure 3 illustrates the classification of the different types of goods identified as unexploited opportunities. We see that most of the opportunities are in household and consumer goods. Food and beverages for primary household consumption include beans, dried fish and other cod, plums and sloes (fresh), strawberries (fresh) and spices. Consumer goods include primarily freezers, carpets, clothing, hair products and table linen. Food and beverages processed for household consumption include unroasted cereal, prepared or preserved potatoes, mixtures of juices, soya bean oil, mixtures of vegetables, homogenised composite food preparations and preserved olives. With Africa being home to more than 1.1 billion people and with more and more Africans entering the consumer class as their economic conditions and purchasing power improve, the demands for household and consumer goods are growing. These unexploited intraregional trade opportunities are a proof of this consumerdriven potential for regional trade.

Also the processed industrial supplies are worth mentioning, making up $20 \%$ of the unexploited trade opportunities within the region. Processed industrial supplies include flat-rolled products of iron or non-alloy steel, ceramic flooring blocks, unglazed ceramic tiles, organic surface-active agents and copper tubes and pipes. This illustrates that African countries have intra-regional trade potential in more processed, industrial goods, which could potentially be a step in the right direction for further industrialisation.

\section{Conclusion and recommendations}

Africa's intra-regional trade is the lowest in the world and its attempts at achieving regional economic integration are possibly some of the most complex. Regional trade and integration in Africa means creating new networking interactions between countries, expanding possibilities of 
TABLE 8: Top 20 importer-product-exporter matches with zero trade (new intra-regional trade opportunities) 2010-2014.

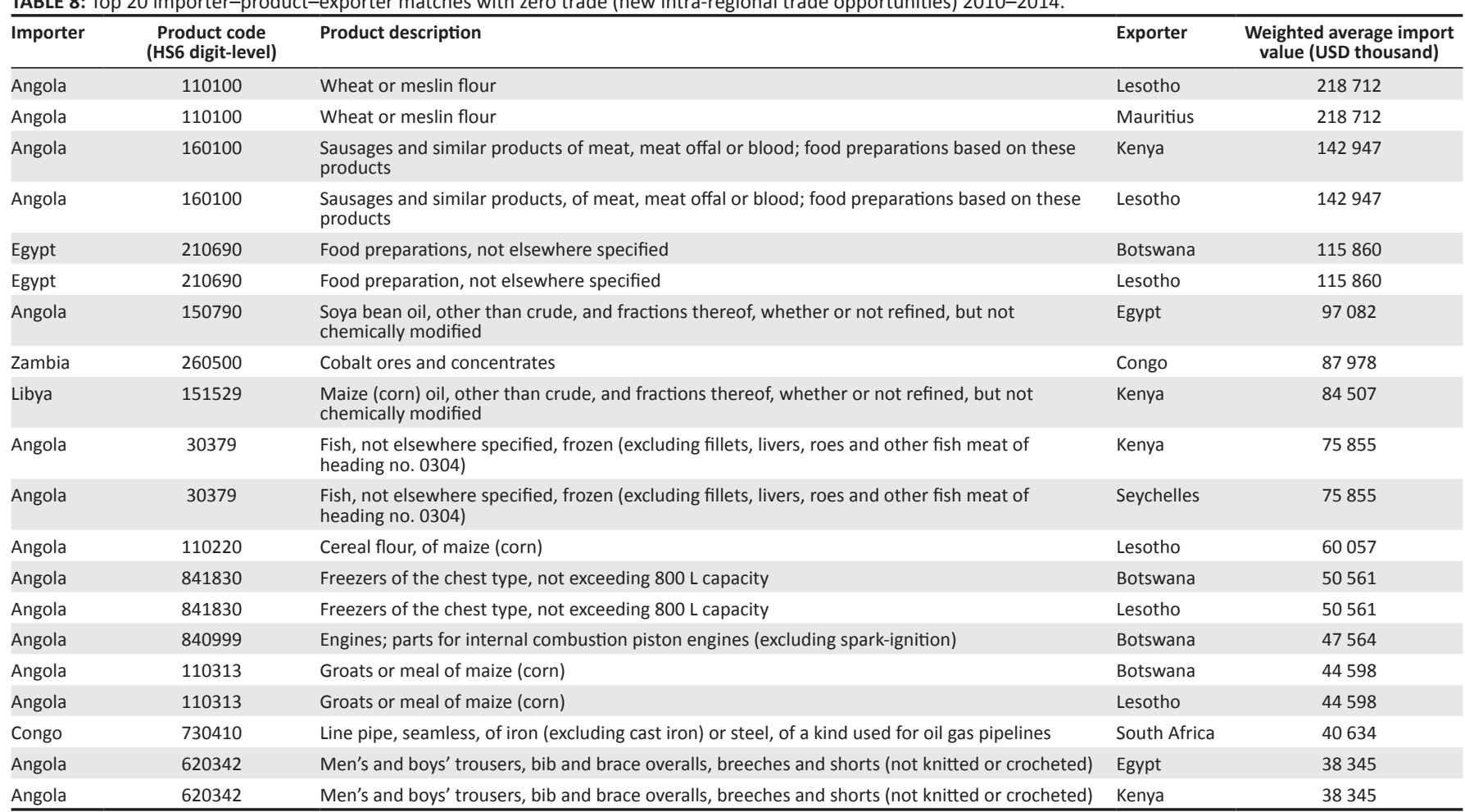

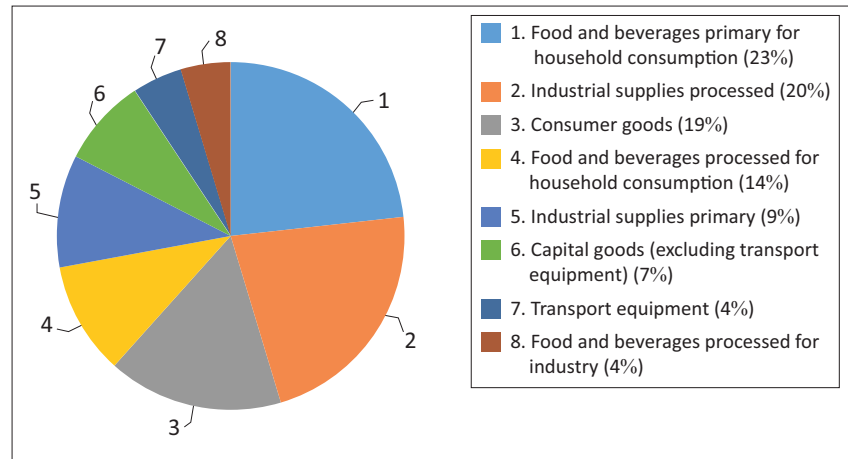

FIGURE 3: Categorisation of the number of unexploited regional trade opportunities: Percentage of unexploited trade by value.

intra-regional trade and giving access to new markets. If successful, economic theory predicts that increased regional trade will also provide the countries involved with the opportunity to address constraints to export competitiveness, improve infrastructure and help to facilitate trade with both itself and the rest of the world. Moreover, a larger market and the pooling of economies through regional integration should create economies of scale.

However, history shows that progress in this regard has been limited and significant structural and policy challenges need to be overcome. It is undeniable that the complex issues of overlapping memberships and conflicting terms of the agreement need to be resolved among member states to allow successful implementation of the TFTA. Although these are real and relevant issues that need to be addressed, it is likely to be a lengthy process. Meanwhile, it is important to determine where opportunities for trade exist in order to address the prevailing low level of intra-regional trade.
The objective of this article is to show that African countries have a unique opportunity to trade with a relatively untapped market: itself. For this reason, the article identifies specific underexploited and unexploited intra-regional opportunities to increase trade on an importer-product-exporter level in the TFTA region. A total of 334 matched opportunities were identified between the 26 countries (between 2010 and 2014). However, only 74 of the 334 opportunities (22\%) show an increase in actual trade in this period, whereas 17 show a decline and 11 have become extinct. Of the unexploited opportunities, a total of 232 new matches (70\%) were identified mainly in vegetable products, foodstuffs, textiles and metals. This means that $78 \%$ of the matched trade opportunities are underexploited or unexploited. These opportunities imply that regardless of the consistently large and growing import demand for the product that can be matched with competitive export supply within the region, there has been declining or no actual trade in the specified period. This means that the import demands in the region are being supplied by countries outside the region.

Further research is needed to identify the reasons why these intra-regional trade opportunities have not been exploited. These reasons may include strong existing trade relationships with countries outside the region, price competitiveness, quality and quantity requirements, trade barriers such as tariff or non-tariff measures, poor infrastructure, timely border and customs procedures, documentation requirements and high transportation costs. It might also be that these importing and exporting countries are not aware of the opportunity to trade within the region (WTO \& OECD 2015).

This study reveals regional trade opportunities in processed products, implying that selected countries in the TFTA 
specialise in the production and export of not only primary commodities but also more processed goods. Even though Africa's production base is low- to medium-skilled and consists of resource-based manufacturing, exploiting the newly recognised intra-regional trade opportunities in processed goods, especially in Africa's growing consumer market, could potentially be a first step to increased competitiveness and even expanded industrialisation. Furthermore, with the Continental Free Trade Agreement (CFTA) negotiations under way, this study can be expanded by including all African countries. This would help to identify possible trade opportunities between all African countries that are not being utilised and could potentially increase intra-regional trade in Africa.

It would be unfortunate if the TFTA was simply a merger of the existing three trade regimes. The literature indicates consensus that the current economic communities have not yet been successful in making intra-regional trade in Africa a powerful driver of economic growth and development. Thus, the main challenge faced by the tripartite policymakers is how to make the envisaged FTA work better than the existing RECs. It is important to be realistic about the ambitious goals set in the TFTA, taking into account what is feasible in the medium to long run, while acknowledging the complex entanglements of combining three RECs. In the short run, these newly revealed trade opportunities can take the integration efforts of policymakers forward. We believe, therefore, that this study contributes valuable information for the promotion of intra-regional trade in Africa.

\section{Acknowledgements}

The authors acknowledge the financial assistance of the World Trade Organization (WTO) towards this research.

\section{Competing interests}

The authors declare that they have no financial or personal relationships that may have inappropriately influenced them in writing this article.

\section{Authors' contributions}

This article forms part of a PhD study of the Trade and Development (TRADE) research focus area of the North-West University by L.F. with E.A.S. as the supervisor and also assisted with the conceptual construction of the study.

\section{Ethical consideration}

This article followed all ethical standards for research without direct contact with human or animal subjects.

\section{Funding information}

This research was financially supported by the World Trade Organization (WTO). Opinions expressed and conclusions arrived at in this article are those of the authors and should not necessarily be attributed to the WTO.

\section{Data availability statement}

Data sharing is not applicable to this article as no new data were created or analysed in this study.

\section{Disclaimer}

This manuscript has not been published and is not under consideration for publication elsewhere. We also have no conflicts of interest to disclose. All authors have approved the manuscript and agree with its submission to the South African Journal of Economic and Management Sciences.

\section{References}

Abdel J.T., 1971, 'A review article: The relevance of traditional integration theory to less developed countries', Journal of Common Market Studies 9(3), 254-267. https://doi.org/10.1111/j.1468-5965.1971.tb01001.x

African Development Bank (AfDB), African Union Commission (AUC) \& United Nations Economic Commission for Africa (ECA), 2016, The Africa Regional Integration Index: 2016 Report, viewed 15 May 2017, from https://www.uneca.org/ publications/africa-regional-integration-index-report-2016.

Babatunde, M.A. \& Odularu, G., 2017, 'Understanding bilateral trade flows and negotiating South-South RTAs: Lessons and policy directions for the Tripartite Free Trade Area Agreement (TFTA)', in G. Odularu \& B. Adekunle (eds.), Negotiating South-South regional trade agreements. Advances in African economic, social and political development, pp. 115-126, Springer, Cham.

Balassa, B., 1965, Trade liberalisation and revealed comparative advantage, Yale University Economic Growth Centre, Newhaven, CT.

Burfisher, M.E., Robinson, R. \& Thierfelder, K., 2004, 'Regionalism: Old and new, theory and practice', in G. Anania, M.E. Bohman, C.A. Carter \& A.F. McCalla (eds.), Agricultural policy reform and the WTO: Where are we heading?, Edward Elgar Cheltenham.

CEPII, 2020, BACl, viewed 10 January 2020, from http://www.cepii.fr/CEPII/en/bdd_ modele/presentation. asp?id=37.

Cuyvers, L., De Pelsmacker, P., Rayp, G. \& Roozen, I., 1995, 'A decision support model for the planning and assessment of export promotion activities by government
promotion institutions: The Belgian case', International Journal of Research in Marketing 12(2), 173-186. https://doi.org/10.1016/0167-8116(94)00021-F

Cuyvers, L., 1997, 'Export opportunities of Thailand: A decision support model approach', Journal of Euro-Asian Management 2(2), 71-97.

Cuyvers, L., 2004, 'Identifying export opportunities: The case of Thailand', International Marketing Review 21(3), 255-278. https://doi.org/10.1108/02651330410539611

Cuyvers, L., Steenkamp, E. \& Viviers, W., 2012, 'The methodology of the decision support model (DSM)', in L. Cuyvers \& W. Viviers (eds.), Export promotion: A decision support model approach, pp. 183-284, Sun Press, Stellenbosch.

Cuyvers, L., Steenkamp, E., Viviers, W., Rossouw, R. \& Cameron, M., 2017, 'Identifying Thailand's high-potential export opportunities in ASEAN+3 countries', Journal of International Trade Law and Policy 16(1), 2-33. https://doi.org/10.1108/ JITLP-09-2016-0019

Demas, W.G., 1965, The economics of development in small countries with specia reference to the Caribbean, McGill University Press, Montreal.

De Melo, J., Panagariya, A. \& Rodrik, D., 1993, 'The new regionalism: A country perspective', Policy Research Working Paper Series 1094, The World Bank, Washington, DC

Garlinska-Bielawska, J., 2016, 'Globalization and regional economic integration in Africa: The new opportunities caused by tripartite free trade area (TFTA)', 13th International conference of the economist society of Thessaloniki: Financial crisis, geopolitical developments and entrepreneurial opportunities, Thessaloniki, 24-26 November.

Hartzenberg, T., 2011, 'Regional integration in Africa', Staff Working Paper ERSD2011-2014, World Trade Organisation Economic Research and Statistics Division, Geneva.

Inama, S. \& Crivelli, P., 2014, 'Can the tripartite free trade area (TFTA) deliver effective and real trade liberalization for economic growth?', Paper presented at the 17th annual conference on global economic analysis, Dakar, Senegal, Purdue University, Global Trade Analysis Project (GTAP), West Lafayette, IN, viewed 20 June 2017, from https://www.gtap.agecon.purdue.edu/resources/res display.asp?RecordID $=4537$.

Jessen, A. \& Vignoles, C., 2004. Trinidad and Tobago: Trade performance and policy issues in an era of growing liberalisation, viewed 18 August 2017, from http:// idbdocs.iadb.org/wsdocs/getdocument.aspx?docnum=33036620.

Juma, C. \& Mangeni, F., 2015, The benefits of Africa's new free trade area, viewed 23 July 2017, from https://www.belfercenter.org/publication/benefits-africas-newfree-trade-area-0.

Keane, J., 2016, Regional integration, sustainable development and global value chains in Southern Africa, viewed 15 March 2017, from https://www.saiia.org.za/ value-chains-in-southern-africa/1062-015-ri-sust-dev-and-gvcs-in-s-afr-jkeane180915/file. 
Lawrence, R.Z., 1997, 'Preferential trading arrangements: The traditional and the new', in A. Galal \& B. Hoekman (eds.), Regional partners in global markets: Limits and possibilities of the Euro-Med agreements, chapter 2, pp. 13-34, Center for Economic
Policy Research (CEPR) and the Egyptian Center for Economic Studies (ECES), Cairo.

Luke, D. \& Mabuza, Z., 2015, 'The tripartite free trade are agreement: A milestone for Africa's regional integration process', Bridges Africa 4(6).

Matthee, M., Idsardi, E. \& Krugell, W., 2015, 'Can South Africa sustain and diversify its exports?', South African Journal of Economic and Management Sciences 19(2) 249-263. https://doi.org/10.4102/sajems.v19i2.1324

Maruping, M., 2005, 'Challenges for regional integration in sub-Saharan Africa: Macroeconomic convergence and monetary coordination', J.J. Teunissen \& A Akkerman (eds.), Africa in the world economy: The national, regional and international challenges, pp. 129-155, Fondad, The Hague.

Mhonyera, G., Steenkamp, E. \& Matthee, M., 2018, 'Evaluating South Africa's utilisation of sustained export potential in sub-Saharan Africa', South African Journal of Economic and Management Sciences 21(1), a1927. https://doi.org/ 10.4102/sajems.v21i1.1927

Mikesell. R.F., 1963. 'The theory of common markets as applied to regional arrangements among developing countries', in R. Harrod \& D. Hague (eds.), International trade theory in a developing world, International Economic Association Series, pp. 205-229, Palgrave Macmillan, London.

Mold, A. \& Mukwaya, R., 2017, 'Modelling the economic impact of the tripartite free trade area: Its implications for the economic geography of Southern, Eastern and Northern Africa', Journal of African Trade 3(1-2), 57-84. https://doi.org/10.1016/j. joat.2017.05.003

Ndomo, A., 2009, Regional economic communities: A progress overview, viewed 15 June 2017, from https://www.g20dwg.org/documents/pdf/view/113/

OECD/WTO, 2015, Aid for trade at a glance 2015: Reducing trade costs for inclusive sustainable growth, OECD Publishing, Paris. viewed 26 July 2017, from https:// doi.org/10.1787/aid glance-2015-en

Perdikis, N., 2007, 'Trade agreements: Depth of integration', in W.A. Kerr \& J.D. Gaisford (eds.), Handbook on international trade policy, pp. 106-119, Edward Elgar, Cheltenham.

Robson, P., 1994, The economics of international integration, 2nd edn., George Allen \& Unwin, London.
Rueda-Junquera, F, 2006, 'European integration model: Lessons for the Central American common market', Jean Monnet/Robert Shuman Paper Series 6 (4), University of Miami, Miami, FL.

Sakamoto, J., 1969, 'Industrial development and integration of underdeveloped countries', Journal of Common Market Studies 7(4), 283-304. https://doi.org/ 10.1111/j.1468-5965.1969.tb00978.x

Sheer, A., 1981, 'A survey of the political economy of customs unions', Law and Contemporary Problems 44(3), 33-53. https://doi.org/10.2307/1191209

United Nations Conference on Trade and Development (UNCTAD), 2017, UNCTADStat database, viewed 15 May 2017, from https://unctadstat.unctad.org/EN/.

United Nations Economic Commission for Africa (UNECA), 2012, Assessing regional integration in Africa V: Towards and African continental free trade area, viewed 12 February 2017, from https://www.uneca.org/publications/assessing-regionalintegration-africa-v.

United Nations Economic Commission for Africa (UNECA), 2016, Africa regiona integration index, viewed 12 July 2017, from https://www.uneca.org/publications/ africa-regional-integration-index-report-2016.

Viner, J., 1950, The customs union issue, Carnegie Endowment for International Peace, Stevens \& Sons, New York.

UNCTAD, 2007, Trade, trade facilitation and transit transport issues for landlocked developing countries, viewed 16 February 2017, from https://unohrlls.org/ UserFiles/File/Elle\%20Wang\%20Uploads/LLDCs\%2OPublication.pdf.

UNCTAD, 2019, Economic development in Africa: Report 2019, viewed 15 December 2019, from https://unctad.org/en/PublicationsLibrary/aldcafrica2019_en.pdf

Walters, L., Bohlmann, H.R. \& Clance, M.W., 2016, 'The impact of the COMESA-EACSADC tripartite free trade agreement on the South African economy', ERSA Working paper, No. 635, September 2016

Willenbockel, D., 2013, General equilibrium assessment of the COMESA-EAC-SADC TFTA FTA, viewed 18 June 2017, from https://mpra.ub.uni-muenchen.de/51501/. MPRA Paper No. 51501.

World Bank, 2015, Deepening African integration: Intra-Africa trade for development and poverty reduction, viewed 08 May 2017, from https://www.worldbank.org/ en/news/speech/2015/12/14/deepening-african-integration-intra-africa-tradefor-development-and-poverty-reduction. 